\title{
CẬP NHẬT HƯớNG DẪN ĐIỀU TRỊ BÓC TÁCH ĐỘNG MẠCH CHỦ NGỰC TYPE B CỦA HIỆP HộI MẠCH MÁU CHÂU ÂU (ESVS)
}

Phan Quốc Hùng*, Trần Quyết Tiến ${ }^{* *}$, Phạm Minh Ánh"

\section{Bóc tách động mạch chủ ngực type $B$ cấp tính}

\section{1. Định nghĩa, yếu tố nguy cơ, triệu chúng lâm sàng}

Bóc tách động mạch chủ ngực cấp tính type B (ATBAD) là do rách lớp nội mạc động mạch dẫn đến tình trạng dòng máu chảy vào lớp áo giữa tạo nên lòng thật và lòng giả của động mạch chủ. Lố rách nguyên uỷ của bóc tách thường gặp nhất trong $\mathrm{ATBAD}$ nằm ngay sau gốc động mạch dưới đòn trái. Trong 90\% các trường hợp, ATBAD có lỗ rách thứ phát cho phép dòng máu chảy vào lại lòng thật.

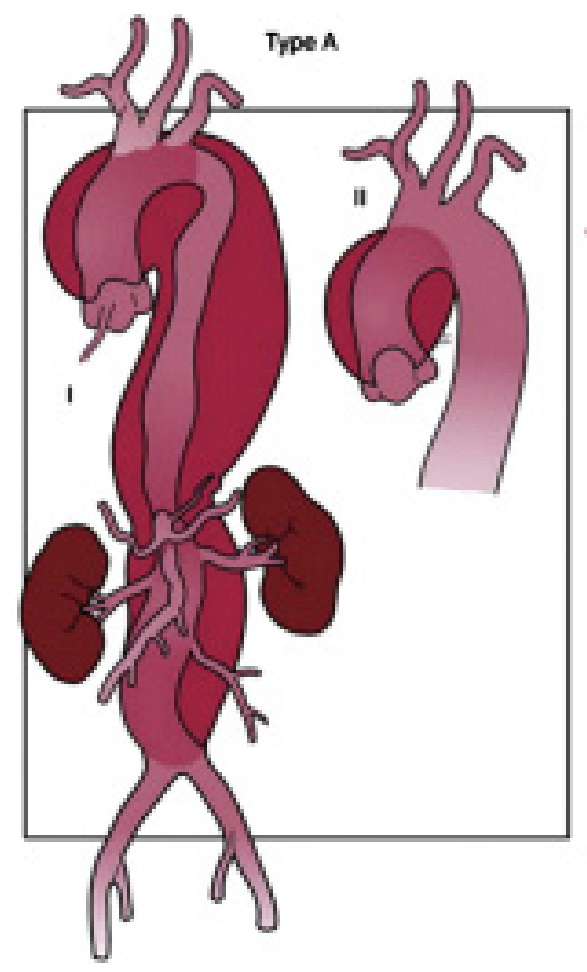

ATBAD thường được mô tả bằng phân loại của Stanford và DeBakey. DeBakey phân loại dựa vào vị trí của lỗ rách nội mạc nguyên uỷ và mức độ kéo dài của bóc tách. Phân loại Standford dựa vào sự liên quan đến động mạch chủ ngực đoạn lên. Bóc tách type A liên quan và bóc tách type $\mathrm{B}$ không liên quan đến động mạch chủ lên. Không có sự đồng thuận nào về phân loại bóc tách đoạn quai động mạch chủ mà không liên quan đến động mạch chủ lên. Bóc tách type $\mathrm{B}$ xuất phát từ sau gốc động mạch dưới đòn trái.

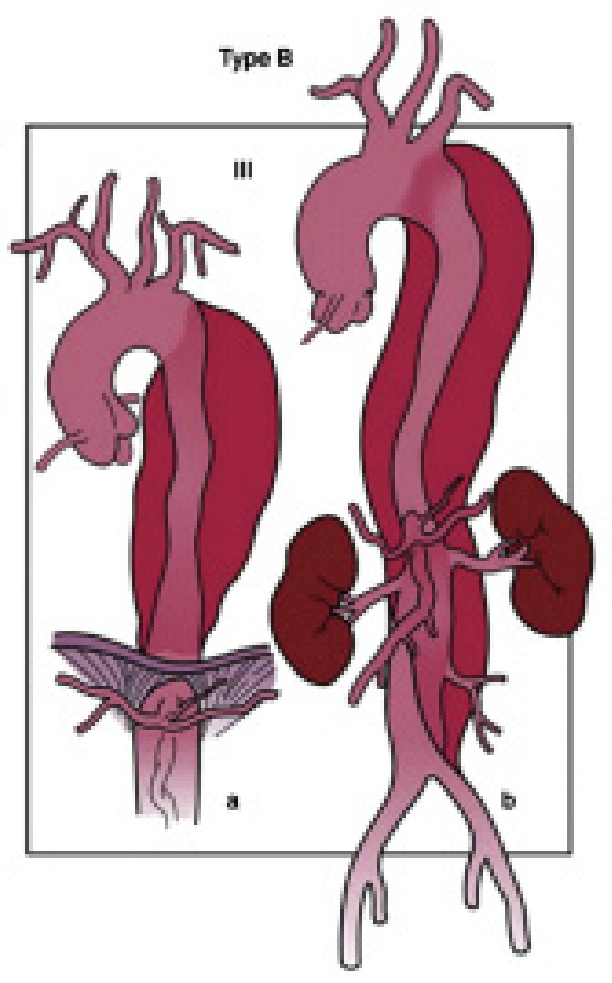

Hinh 1. Phân loại bóc tách động mạch chủ

ATBAD chiếm khoảng 30-40\% các trường hợp bóc tách động mạch chủ. Bóc tách cấp tính được tính trong vòng 14 ngày kể từ khi bắt đầu có triệu chứng. Từ 14 ngày -3 tháng được gọi là bán cấp, và sau 3 tháng được gọi là mãn tính.
* Khoa Phẫu thuật mạch máu, Bệnh viện Chợ Rẫy

**Khoa Phẫu thuật tim, Bệnh viện Chợ Rẫy

Người chịu trách nhiệm khoa học: PGS.TS. Trần Quyết Tiến

Ngày nhận bài: 01/05/2018 - Ngày Cho Phép Đăng: 20/05/2018

Phản Biện Khoa học: PGS.TS. Đặng Ngọc Hùng GS.TS. Lê Ngọc Thành 
Các điều kiện làm gia tăng áp lực lên lỗ rách và làm yếu đi sự bền vững của thành mạch được xem là các yếu tố nguy cơ. Tăng huyết áp chiếm tỷ lệ $80 \%$ trong ATBAD. Tuổi cao, xơ vữa động mạch, van động mạch chủ 2 mảnh, nghiện ma tuý, hoạt động thể lực mạnh, sang chấn tâm lý trầm trọng là những yếu tố nguy cơ quan trọng khác. Một yếu tố nguy cơ quan trọng khác là tiền sử gia đình bị bệnh động mạch chủ ngực. Tỷ lệ 13-22\% bệnh nhân ATBAD có cha mẹ hoặc anh chị em ruột mắc bệnh phình hay bóc tách động mạch chủ. "Hội chứng bóc tách và bệnh động mạch chủ ngực gia đình" liên quan đến một số các đột biến gen bao gồm FBN1, TGFBR1, TGFBR2, ACTA, MYH11 gia tăng sự hiểu biết sâu sắc về bệnh học di truyền của bệnh lý này.

Sự yếu đi cấu trúc thành mạch liên quan với một số rối loạn mô liên kết như hội chứng Marfan, hội chứng Ehler-Danlos, hội chứng Loyes-Dietz. Ở bệnh nhân bóc tách động mạch chủ dưới 40 tuổi, khoảng 50\% các trường hợp có hội chứng Marfan hoặc liên quan đến rối loạn di truyền. Nhóm bệnh nhân này và nhóm có tiền sử gia đình bị bệnh động mạch chủ nên được tầm soát về di truyền. Đường kính động mạch chủ không liên quan chặt chẽ đến ATBAD, mặc dù nguy cơ ATBAD gia tăng ở bệnh nhân có động mạch chủ ngực đoạn xuống dãn. Đường kính động mạch chủ trung bình đo được trong ATBAD khoảng $41 \mathrm{~mm}$. Trong thực tế, nhiều trường hợp $\mathrm{ATBAD}$ có đường kính động mạch chủ bình thường.

Triệu chứng lâm sàng của $\mathrm{ATB} A D$ đa dạng và có thể tương tự nhiều bệnh lý khác. Đau ngực dữ dội hoặc đau giữa hai vai chiếm khoảng $80 \%$ các trường hợp $\mathrm{ATBAD}$. Những triệu chứng chính được liệt kê trong bảng dưới đây:

\begin{tabular}{|l|c|}
\hline Triệu chứng & Tần suất, \% \\
\hline Đau ngực, đau giữa 2 vai dữ dội & 80 \\
\hline Đau ngực & 79 \\
\hline Đau lưng & 64 \\
\hline
\end{tabular}

\begin{tabular}{|l|c|}
\hline Đau bụng & 43 \\
\hline Ngất & 4 \\
\hline Yếu hay mất mạch & 9 \\
\hline Tụt huyết áp/Choáng & 4 \\
\hline Thiếu máu tạng & 7 \\
\hline Thiếu máu thận & 15 \\
\hline Thiếu máu chi & 9 \\
\hline $\begin{array}{l}\text { Đau dai dẳng hoặc tăng huyết áp } \\
\text { dai dẳng }\end{array}$ & 18 \\
\hline Thiếu máu tuỷ & 3 \\
\hline
\end{tabular}

Theo IRAD, tụt huyết áp, không có triệu chứng đau ngực/lưng, tổn thương bóc tách liên quan đến các nhánh là những yếu tố tiên lượng tử vong tại bệnh viện.

Hầu hết bệnh nhân bóc tách động mạch chủ đều có triệu chứng. Tuy nhiên, một số trường hợp biểu hiện lâm sàng không đặc hiệu hoặc không có triệu chứng dẫn đến chẩn đoán chậm trễ.

Biến chứng trầm trọng nhất của $\mathrm{ATBAD}$ là vỡ động mạch chủ và tắc các nhánh động mạch. Tỷ lệ tử vong cao đối với vỡ động mạch chủ. Những trường hợp doạ vỡ không có rối loạn huyết động có kết quả điều trị tốt hơn.

Thiếu máu thận/tạng đôi khi khó nhận thấy. Thiếu máu thận làm tăng creatinin máu và khả năng dẫn đến tăng huyết áp khó kiểm soát. Điều trị thiếu máu thận rất quan trọng để ngăn ngừa suy thận vĩnh viễn hoặc tăng huyết áp dai dẳng làm gia tăng kích thước của động mạch chủ bị bóc tách. Thiếu máu tạng là nguyên nhân tử vong đứng hàng thứ ba (sau vỡ động mạch chủ và chèn ép tim) trong bóc tách động mạch chủ theo nghiên cứu IRAD, nguyên nhân do tưới máu sai lòng và tụt huyết áp. Bệnh nhân $\mathrm{ATBAD}$ có triệu chứng đau bụng tái diê̂n cần chụp cắt lớp vi tính lại. Xuất huyết tiêu hoá là một biến chứng hiếm gặp và những bệnh nhân có triệu chứng này kèm với đau bụng cần nghĩ đến thiếu máu mạc treo ruột. Thiếu máu chi cấp tính có thể kèm theo liệt 
chi dưới một bên hay hai bên. Yếu liệt hai chi dưới là một biến chứng tuy hiếm nhưng thảm khốc đối với bệnh nhân ATBAD do thiếu máu tuỷ sống. Những biến chứng khác như đau và tăng huyết áp dai dẳng là những dấu hiệu gián tiếp của tình trạng bóc tách doạ vỡ, làm gia tăng tỷ lệ tử vong tại bệnh viện.

ATBAD có biến chứng gồm: tăng nhanh kích thước của động mạch chủ, vỡ động mạch chủ và/hoặc tụt huyết áp/choáng, thiếu máu chi, thiếu máu thận, thiếu máu tạng, yếu/liệt hai chi dưới, tụ máu quanh động mạch chủ, đau tái phát hoặc đau dai dẳng, tăng huyết áp dai dẳng mặc dù đã điều trị nội khoa tối ưu.

Tỷ suất sống còn tại bệnh viện của bệnh nhân ATBAD có biến chứng được điều trị bảo tồn khoảng $50 \%$. Tụt huyết áp/choáng và thiếu máu tạng là yếu tố tiên lượng quan trọng nhất đối với tử vong tại bệnh viện.

Bệnh nhân ATBAD có biến chứng kèm nhiều bệnh phối hợp trầm trọng như bệnh tim thiếu máu cục bộ, bệnh phổi mãn tính, ung thư cần được đánh giá theo từng trường hợp cụ thể. Điều trị xâm lấn ở những bệnh nhân này không có nhiều lợi ích.

\begin{tabular}{|c|c|c|}
\hline Khuyến cáo 12 & $\begin{array}{c}\text { Mức độ } \\
\text { khuyến } \\
\text { cáo }\end{array}$ & $\begin{array}{c}\text { Mức độ } \\
\text { bằng } \\
\text { chứng }\end{array}$ \\
\hline $\begin{array}{l}\text { Bệnh nhân bóc tách } \\
\text { động mạch chủ cấp tính } \\
\text { type B có triệu chứng } \\
\text { đau bụng tái phát, nghi } \\
\text { ngờ tưới máu sai lòng } \\
\text { thận, tạng, và/hoặc 2 } \\
\text { chi dưới nên được chụp } \\
\text { cắt lớp vi tính lại. }\end{array}$ & $\mathrm{C}$ \\
\hline
\end{tabular}

Khoảng 50\% trường hợp ATBAD không có biến chứng. Một nghiên cứu đoàn hệ ghi nhận bệnh nhân ATBAD không biến chứng có tỷ lệ tử vong tại bệnh viện 3-10\%. Ở nhóm bệnh nhân có biến chứng (thiếu máu thận, tạng, hoặc chi, và/hoặc vỡ động mạch chủ), tỷ lệ tử vong tăng lên $20 \%$ vào ngày thứ 2 và $25 \%$ vào ngày thứ 30). Tương tự bóc tách type $\mathrm{A}$, tuổi cao, vỡ động mạch chủ, choáng, tưới máu sai lòng là những yếu tố tiên lượng quan trọng làm gia tăng tỷ lệ tử vong sớm.

\section{2. Điều trị}

Mục tiêu điều trị ATBAD là duy trì và phục hồi tưới máu các cơ quan sống còn, ngăn ngừa tiến triển của bóc tách và vỡ động mạch chủ. Vì vậy, cần phải đánh giá các nguy cơ kỹ lưỡng trong giai đoạn sớm để xác định lợi ích của điều trị nội khoa, can thiệp nội mạch và phẫu thuật.

\subsection{1. Điều trị nội khoa}

Điều trị nội khoa tình trạng tăng huyết áp là cơ bản đối với ATBAD không biến chứng. Mục đích làm giảm áp lực lên thành động mạch chủ và giảm phân xuất tống máu của thất trái. Huyết áp tâm thu mục tiêu là $100-120 \mathrm{mmHg}$ và nhịp tim dưới 60 lần/phút. Chẹn beta là thuốc đầu tay trong điều trị ATBAD. Ở những bệnh nhân không đáp ứng hoặc không dung nạp với chẹn beta, thay thế bằng các thuốc đối kháng canxi và/hoặc ức chế renin-angiotensin. Thuốc chẹn beta và đối kháng canxi làm tăng tỷ suất sống còn của bệnh nhân ATBAD.

Giảm đau cũng quan trọng trong tối ưu hoá điều trị nội khoa, bởi vì đau dai dẳng là chỉ điểm của bóc tách tiến triển hoặc doạ vỡ. Trong thời gian nằm viện, điều trị thuốc qua đường tĩnh mạch nên chuyển sang đường uống, và theo dõi huyết áp lâu dài, đầy đủ là bắt buộc.

\subsubsection{Can thiệp nội mạch (TEVAR)}

TEVAR được xem là lựa chọn điều trị đầu tiên đối với $\mathrm{ATBAD}$ có biến chứng. Mục tiêu của TEVAR trong điều trị ATBAD có biến chứng doạ vỡ hoặc tưới máu sai lòng là che phủ lỗ rách nguyên uỷ và làm giảm áp lực trong lòng giả. Giảm tưới máu trong lòng giả có thể ngăn ngừa tiến triển của bóc tách, dẫn đến huyết khối lòng giả, tái cấu trúc động mạch chủ. 
Mặc dù không có nghiên cứu ngẫu nhiên nào nhưng nhiều bằng chứng cho thấy trong ATBAD có biến chứng, can thiệp cấp cứu có lợi cho bệnh nhân. TEVAR có lợi thế đáng kể so với phẫu thuật trong tỷ lệ tử vong sớm của bệnh nhân ATBAD.

Hiện tại, có 3 nghiên cứu phân tích gộp đánh giá kết quả ngắn hạn và trung hạn của TEVAR trong điều trị $\mathrm{ATBAD}$ có biến chứng. Tỷ lệ thành công về mặt kỹ thuật dao động từ 95-99\%, tỷ lệ tử vong tại bệnh viện $2.6-9.8 \%$ và biến chứng thần kinh từ 0.6-3.1\%. Một nghiên cứu đăng bộ lâm sàng tiền cứu, đa trung tâm ở châu Âu trên 50 bệnh nhân ATBAD cho thấy tỷ lệ tử vong chu phẫu là $8 \%$, đột quỵ $8 \%$ và biến chứng thiếu máu tuỷ sống $2 \%$.

Kết quả bước đầu của nghiên cứu đa trung tâm, đơn nhánh điều trị ATBAD có biến chứng bằng TEVAR tiêu chuẩn kết hợp với đặt giá đỡ nội mạch trần đoạn động mạch chủ dưới cơ hoành (kỹ thuật PETTICOAT) có tỷ lệ tử vong 1 năm là $10 \%$. Tỷ lệ đột quy, thiếu máu não thoáng qua, hoặc bóc tách tiến triển lần lượt là $7.5 \%, 2.5 \%$ và $5 \%$. Một nghiên cứu khác cho thấy tỷ lệ tử vong tại bệnh viện đối với ATBAD có biến chứng được điều trị bằng $\mathrm{TEVAR}$, phẫu thuật và nội khoa là $4 \%, 40 \%$ và $33 \%$. Tuy nhiên, không có bằng chứng chứng minh sự che phủ kéo dài động mạch chủ ngực đoạn xuống là cần thiết để phục hồi tình trạng tưới máu xa. Những bệnh nhân ATBAD biến chứng tưới máu tạng sai lòng có kết quả điều trị kém nhất. Mặc dù tỷ suất tái thông các mạch máu nuôi tạng lên đến $97 \%$ sau TEVAR, tỷ lệ tử vong chu phẫu cao (17-34\%) và các biến chứng liên quan đến động mạch chủ cao trong giai đoạn mãn tính sau đó. Tưới máu sai lòng động học có thể điều trị bằng gia tăng dòng chảy ở lòng giả đoạn xa bằng cách mở cửa sổ vách nội mạc giữa lòng thật và lòng giả. Tưới máu sai lòng tĩnh học hoặc tắc gốc của động mạch tưới máu sai lòng nên được điều trị bằng đặt giá đỡ nội mạch.

TEVAR cũng được thừa nhận trong điều trị ATBAD không biến chứng, ngăn ngừa biến chứng dãn động mạch chủ và vỡ về lâu dài.
Nghiên cứu IRAD cho thấy tỷ lệ tử vong sau 5 năm giảm ở bệnh nhân $\mathrm{ATBAD}$ điều trị bằng TEVAR so với điều trị nội khoa.

ADSORD, nghiên cứu ngẫu nhiên duy nhất với bệnh nhân ATBAD không biến chứng cho thấy không có khác biệt về tỷ lệ tử vong tại thời điểm 1 năm. Tuy nhiên, tỷ lệ huyết khối lòng giả cao hơn ở nhóm bệnh nhân TEVAR. Huyết khối lòng giả làm giảm tỷ lệ biến chứng muộn và gia tăng sự tái cấu trúc động mạch chủ sau TEVAR.

Mặc dù kết quả điều trị ATBAD bằng TEVAR rất hứa hẹn, những biến chứng của can thiệp nội mạch cũng trầm trọng và có thể cần phải phẫu thuật. Đột quỵ chiếm 3-10\% sau TEVAR do thao tác trên động mạch chủ lên và quai động mạch chủ, thường gặp ở bệnh nhân xơ vữa quai động mạch chủ nặng.

Thiếu máu tuỷ sống ít gặp, nguyên nhân do che phủ động mạch chủ quá dài, tiền sử phẫu thuật động mạch chủ hay tụt huyết áp lúc nhập viện. Thiếu máu chi trên, yếu liệt có thể xảy ra do che phủ động mạch dưới đòn trái và các động mạch liên sườn cần được phục hồi lưu thông mạch máu.

Một số biến chứng khác liên quan đến dụng cụ và kỹ thuật can thiệp bao gồm vỡ động mạch chủ khi bung dụng cụ, gập góc, di lệch, gãy ống ghép nội mạch, giả phình đầu gần và đầu xa ống ghép, thủng ống ghép. Bóc tách type $\mathrm{A}$ ngược dòng là biến chứng cực kỳ trầm trọng. TEVAR đối với bóc tách động mạch chủ dễ gây ra bóc tách type A ngược dòng.

Nguy cơ bóc tách type A ngược dòng gia tăng khi nong bóng đầu gần, đầu gần ống ghép nội mạch có giá đỡ trần.

Can thiệp nội mạch điều trị ATBAD là một thách thức về mặt kỹ thuật và kết quả tối ưu chỉ có thể đạt được ở những trung tâm chuyên sâu, có nhiều kinh nghiệm can thiệp và một đội ngũ đa chuyên khoa phối hợp điều trị bóc tách động mạch chủ. Dãn động mạch chủ mãn tính sau TEVAR cần được theo dõi ở bệnh nhân có lòng giả còn thông. 


\begin{tabular}{|c|c|c|}
\hline Khuyến cáo 13 & $\begin{array}{l}\text { Mức độ } \\
\text { khuyến cáo }\end{array}$ & $\begin{array}{l}\text { Mức độ bằng } \\
\text { chứng }\end{array}$ \\
\hline $\begin{array}{l}\text { Điều trị nội khoa đóng vai trò quan trọng trong điều trị bóc tách } \\
\text { động mạch chủ type } \mathrm{B} \text { cấp tính }\end{array}$ & I & $\mathrm{C}$ \\
\hline \multicolumn{3}{|l|}{ Khuyến cáo 14} \\
\hline $\begin{array}{l}\text { Chẹn beta là thuốc lựa chọn đầu tiên trong điều trị bóc tách động } \\
\text { mạch chủ type B cấp tính }\end{array}$ & IIa & $\mathrm{C}$ \\
\hline \multicolumn{3}{|l|}{ Khuyến cáo 15} \\
\hline $\begin{array}{l}\text { Những bệnh nhân bóc tách động mạch chủ type } \mathrm{B} \text { cấp tính } \\
\text { không đáp ứng hoặc không dung nạp với chẹn beta, thuốc đối } \\
\text { kháng canxi và/hoặc ức chế renin-angiotensin có thể xem xét là } \\
\text { thuốc thay thế }\end{array}$ & $\mathrm{IIb}$ & $\mathrm{C}$ \\
\hline \multicolumn{3}{|l|}{ Khuyến cáo 16} \\
\hline $\begin{array}{l}\text { Ở bệnh nhân bóc tách động mạch chủ type } \mathrm{B} \text { cấp tính có biến } \\
\text { chứng, can thiệp nội mạch là lựa chọn điều trị đầu tiên }\end{array}$ & I & $\mathrm{C}$ \\
\hline \multicolumn{3}{|l|}{ Khuyến cáo 17} \\
\hline $\begin{array}{l}\text { Ở bệnh nhân bóc tách động mạch chủ type } \mathrm{B} \text { có biến chứng, mở } \\
\text { cửa sổ vách nội mạc động mạch chủ bằng can thiệp nội mạch } \\
\text { nên được xem xét để điều trị tưới máu sai lòng }\end{array}$ & IIa & $\mathrm{C}$ \\
\hline \multicolumn{3}{|l|}{ Khuyến cáo 18} \\
\hline $\begin{array}{l}\text { Để phòng ngừa biến chứng liên quan động mạch chủ đối với bóc } \\
\text { tách động mạch chủ type } \mathrm{B} \text { cấp tính không biến chứng, đặt ống } \\
\text { ghép nội mạch sớm có thể được xem xét một cách chọn lọc }\end{array}$ & IIb & B \\
\hline
\end{tabular}

\subsubsection{Phẫu thuật}

Phẫu thuật điều trị ATBAD là cắt bỏ lỗ rách nguyên uỷ, thay đoạn động mạch chủ ngực xuống bằng mạch nhân tạo, phục hồi tưới máu ngoại biên và ngăn ngừa biến chứng vỡ động mạch chủ. Chạy máy tuần hoàn ngoài cơ thể bán phần, hạ thân nhiệt để bảo vệ não được sử dụng trong phẫu thuật ATBAD. Không có nghiên cứu đối chứng ngẫu nhiên nào so sánh các kỹ thuật mổ khác nhau. Những bệnh nhân có biến chứng vỡ, tăng kích thước khối bóc tách nhanh, tưới máu sai lòng thì phẫu thuật có tỷ lệ biến chứng, tử vong cao.

Phẫu thuật mở cửa sổ động mạch chủ hay cầu nối ngoài giải phẫu chỉ được áp dụng điều trị ATBAD có biến chứng khi can thiệp nội mạch thất bại hay chống chỉ định. Mặc dù kết quả phẫu thuật điều trị ATBAD đã có nhiều tiến bộ trong những thập kỷ qua, tỷ lệ biến chứng vẫn còn cao với tỷ lệ tử vong tại bệnh viện từ $25-50 \%$. Tình trạng bệnh nhân trước mổ ảnh hưởng lớn đến kết quả điều trị phẫu thuật. Bệnh nhân $>70$ tuổi có tụt huyết áp hoặc choáng có kết quả kém hơn bệnh nhân có huyết áp bình thường tại thời điểm phẫu thuật. Khoảng $40-80 \%$ bệnh nhân phẫu thuật điều trị ATBAD có biến chứng. Biến chứng thần kinh như yếu chi (2.3-6.6\%), liệt chi (0$3.1 \%)$, và đột quỵ (2.7-6.6\%) liên quan đến mức độ tổn thương và thời gian phẫu thuật. Lợi ích của tuần hoàn ngoài cơ thể đối với sự giảm biến chứng thần kinh và thiếu máu thận vẫn còn bàn 
cãi. Những biến chứng khác của phẫu thuật bao gồm: thiếu máu hay nhồi máu cơ tim, suy hô hấp, thiếu máu tạng, chi, nhiễm trùng, suy đa cơ quan.

\begin{tabular}{|l|c|c|}
\hline \multicolumn{1}{|c|}{ Khuyến cáo 19 } & $\begin{array}{c}\text { Mức độ } \\
\text { khuyến } \\
\text { cáo }\end{array}$ & $\begin{array}{c}\text { Mức độ } \\
\text { bằng } \\
\text { chứng }\end{array}$ \\
\hline $\begin{array}{l}\text { Đối với bóc tách động } \\
\text { mạch chủ cấp tính có } \\
\text { biến chứng, phẫu thuật } \\
\text { được xem xét là } \\
\text { phương pháp thay thế } \\
\text { can thiệp nội mạch khi } \\
\text { chống chỉ định hoặc } \\
\text { can thiệp thất bại }\end{array}$ & IIa \\
\hline
\end{tabular}

\section{Bóc tách động mạch chủ ngực type $B$ mãn tính}

\section{1. Định nghĩa}

Bóc tách động mạch chủ mãn tính được tính từ sau 14 ngày của bóc tách cấp tính. Phân loại này dựa trên bằng chứng khoảng $70 \%$ bệnh nhân bóc tách động mạch chủ tử vong xảy ra trong vòng 2 tuần đầu tiên từ khi có triệu chứng. Tỷ lệ tử vong vẫn ở mức cao trong 3 tháng đầu nên những năm gần đây, thuật ngữ bóc tách động mạch chủ bán cấp (từ thời điểm 2 tuần đến 3 tháng) được tính đến. Can thiệp nội mạch trong khoảng thời gian này có tỷ lệ tái cấu trúc thành động mạch chủ cao hơn.

Nhìn chung, bóc tách động mạch chủ type $B$ mãn tính (CTBAD) bao gồm cả những bệnh nhân bóc tách type $\mathrm{B}$ tồn lưu sau phẫu thuật bóc tách type $\mathrm{A}$. Tỷ lệ biến chứng liên quan động mạch chủ xảy ra ở 20-50\% bệnh nhân CTBAD. Khoảng 20-40\% bệnh nhân CTBAD có gia tăng kích thước lòng giả cần điều trị và $25 \%$ bệnh nhân phình ĐM chủ ngực đoạn xuống hoặc phình động mạch chủ ngực bụng kèm bóc tách.

Ngoài phình bóc tách, biến chứng liên quan động mạch chủ bao gồm: bóc tách tái phát, bóc tách ngược dòng và vỡ lòng giả. Tốc độ tăng kích thước của động mạch chủ trong bóc tách mãn tính dao động từ 1-7 mm hàng năm. Tăng huyết áp, đường kính động mạch chủ $\geq 40 \mathrm{~mm}$ ở giai đoạn cấp tính, bệnh phổi tắc nghẽn mãn tính, lòng giả thông là những yếu tố nguy cơ cho phình bóc tách động mạch chủ muộn. Lỗ rách nguyên uỷ kích thước $>10 \mathrm{~mm}$, hoặc vị trí 1ỗ rách nằm ở quai động mạch chủ hay đoạn gần động mạch chủ xuống là yếu tố tiên đoán đối với tử vong muộn và xử trí tổn thương động mạch chủ về sau.

Ở bệnh nhân được điều trị bóc tách type $\mathrm{A}$, lòng giả đoạn xa thông $(>70 \%$ đường kính toàn bộ động mạch chủ) cũng là một yếu tố tiên đoán cho phình bóc tách. Ngược lại, huyết khối lòng giả làm chậm sự tiến triển của bóc tách. Huyết khối lòng giả bán phần là yếu tố tiên đoán độc lập đối với tử vong sau xuất viện ở bệnh nhân CTBAD. Nguy cơ vỡ phình do bóc tách cao hơn phình do thoái hoá thành mạch mặc dù không có bằng chứng ủng hộ điều trị phình bóc tách có đường kính nhỏ hơn. Tỷ suất sống còn lâu dài sau bóc tách type $\mathrm{B}$ không biến chứng không khả quan. Theo IRAD, tỷ lệ tử vong muộn cao ở bệnh nhân xuất viện sau ATBAD, khoảng 30\% trong thời gian 3 năm. Tử vong đối với $\mathrm{CTBAD}$ liên quan đến các bệnh lý phối hợp.

\section{2. Điều trị}

Điều trị nội khoa tích cực và theo dõi sát cực kỳ quan trọng để giảm nguy cơ tử vong muộn và biến chứng liên quan động mạch chủ. Một nghiên cứu quan sát, không ngẫu nhiên, tỷ suất sống còn cải thiện ở bệnh nhân $\mathrm{CTBAD}$ điều trị với thuốc chẹn beta. Nghiên cứu này ghi nhận tỷ lệ bệnh nhân điều trị với thuốc chẹn beta không có biến chứng liên quan động mạch chủ trong thời gian theo dõi trung bình 4.2 năm là $80 \%$. Trong khi đó, tỷ lệ này ở bệnh nhân điều trị với các thuốc hạ áp khác là 47\%. Hiệu quả của thuốc hạ áp khác không được chứng minh rõ đối với CTBAD mặc dù các thuốc này vẫn duy trì được huyết áp ổn định. 
Một số nghiên cứu cho thấy 40-70\% tử vong muộn ở bệnh nhân CTBAD là do các bệnh phối hợp, quan trọng nhất là bệnh tim mạch và đột quy. Vì vậy, các yếu tố nguy cơ tim mạch cần được đánh giá và điều trị cẩn thận ở nhóm bệnh nhân này. Hút thuốc lá không ảnh hưởng đến tăng kích thước và vỡ động mạch chủ mặc dù vai trò của nó trên nguy cơ tim mạch là rõ ràng.

\begin{tabular}{|l|c|c|}
\hline \multicolumn{1}{|c|}{ Khuyến cáo 30 } & $\begin{array}{c}\text { Mức độ́ } \\
\text { khuyến cáo }\end{array}$ & $\begin{array}{c}\text { Mức độ } \\
\text { bằng chứng }\end{array}$ \\
\hline $\begin{array}{l}\text { Ở bệnh nhân bóc tách động mạch chủ mãn tính, điều trị tăng huyết áp } \\
\text { hiệu quả làm giảm nguy cơ tử vong liên quan đến động mạch chủ }\end{array}$ & I & C \\
\hline Khuyến cáo 31 & & C \\
\hline $\begin{array}{l}\text { Ở bệnh nhân bóc tách động mạch chủ mãn tính, điều trị các yếu tố } \\
\text { nguy cơ tim mạch (rối loạn mỡ máu, điều trị thuốc chống ngưng tập } \\
\text { tiểu cầu, tăng huyết áp, ngưng hút thuốc lá) làm giảm tử vong muộn } \\
\text { do tim mạch }\end{array}$ & I & \\
\hline Khuyến cáo 32 & & \\
\hline $\begin{array}{l}\text { Điều trị lâu dài thuốc chẹn beta đối với bóc tách động mạch chủ mãn } \\
\text { tính không biến chứng vì nó làm giảm sự tiến triển của động mạch } \\
\text { chủ, tần suất tái nhập viện và can thiệp động mạch chủ. }\end{array}$ & I & C \\
\hline
\end{tabular}

\subsubsection{Chi định điều trị}

Mục tiêu chính của xử trí tổn thương động mạch chủ ở bệnh nhân CTBAD là ngăn ngừa biến chứng phình bóc tách và vỡ động mạch chủ. Tưới máu sai lòng cũng cần được điều trị. Chỉ định điều trị dựa trên lâm sàng và hình ảnh học.

Những triệu chứng khởi đầu của hội chứng động mạch chủ cấp, như đau lưng không do nguyên nhân khác, tụt huyết áp, suy giảm mạch ngoại biên, chênh áp, dấu thần kinh khu trú hoặc dấu hiệu tưới máu sai lòng ở bệnh nhân CTBAD cần được đánh giá ngay để loại trừ biến chứng vỡ hoặc tiến triển của bóc tách.

Đối với bệnh nhân CTBAD không triệu chứng, đường kính túi phình là yếu tố quan trọng nhất quyết định điều trị. Đường kính càng lớn nguy cơ vỡ càng cao. Một số tác giả ghi nhận tỷ lệ vỡ khoảng $20 \%$ đối với phình bóc tách đường kính 50-60mm.

\begin{tabular}{|l|c|c|}
\hline \multicolumn{1}{|c|}{ Khuyến cáo 33 } & $\begin{array}{c}\text { Mức độ } \\
\text { khuyến cáo }\end{array}$ & $\begin{array}{c}\text { Mức độ } \\
\text { bằng chứng }\end{array}$ \\
\hline $\begin{array}{l}\text { Ở bệnh nhân bóc tách động mạch chủ mãn tính và có triệu chứng } \\
\text { cấp tính, xử trí cấp cứu nên được xem xét nếu có biến chứng } \\
\text { tưới máu sai lòng, vỡ, hoặc bóc tách tiến triển xác định trên hình } \\
\text { ảnh học }\end{array}$ & IIa \\
\hline Khuyến cáo 34a & C \\
\hline $\begin{array}{l}\text { Ở bệnh nhân bóc tách động mạch chủ mãn tính, đường kính } \\
\text { động mạch chủ ngực xuống từ 56-59mm có thể được chỉ định } \\
\text { điều trị khi nguy cơ phẫu thuật chấp nhận được }\end{array}$ & IIb & C \\
\hline
\end{tabular}




\begin{tabular}{|c|c|c|}
\hline Khuyến cáo 34b & & \\
\hline $\begin{array}{l}\text { Ở bệnh nhân bóc tách động mạch chủ mãn tính, đường kính } \\
\text { động mạch chủ ngực xuông } \geq 60 \mathrm{~mm} \text { nên được chỉ định điều trị } \\
\text { khi nguy cơ phẫu thuật chấp nhận được }\end{array}$ & IIa & C \\
\hline Khuyến cáo 35 & & \\
\hline $\begin{array}{l}\text { Ở bệnh nhân bóc tách động mạch chủ mãn tính, tổn thương lan } \\
\text { toả động mạch chủ ngực-bụng và đường kính động mạch chủ } \geq \\
\text { 60mm nên được chỉ định điều trị khi nguy cơ pẫu thuật chấp } \\
\text { nhận được }\end{array}$ & IIa & C \\
\hline
\end{tabular}

\subsubsection{Phẫu thuật}

Mặc dù không có số liệu so sánh giữa phẫu thuật và can thiệp nội mạch, phẫu thuật vẫn là điều trị tiêu chuẩn đối với CTBAD nguy cơ thấp do sự tiến bộ về kết quả phẫu thuật trong 20 năm qua. Mặc dù một số tác giả báo cáo nguy cơ phẫu thuật thấp là điều kiện tiên quyết đối với phẫu thuật CTBAD, nhưng định nghĩa nguy cơ đối với phẫu thuật động mạch chủ ngực là khó khăn. Cách đánh giá thường được sử dụng trong phẫu thuật tim như EuroSCORE, CICSP cho kết quả trái ngược khi áp dụng đối với phẫu thuật động mạch chủ ngực. Một nghiên cứu tại Nhật Bản ghi nhận thang điểm EuroSCORE có thể tin cậy để tiên đoán tỷ lệ tử vong tại bệnh viện trong 327 trường hợp phẫu thuật động mạch chủ ngực liên tiếp. Ngược lại, một nghiên cứu tại Mỹ trên 100 bệnh nhân phẫu thuật cho thấy cả hai thang điểm EuroSCORE và CICSP đã ước tính quá mức tỷ lệ tử vong phẫu thuật.

Cơ sở chính của phẫu thuật điều trị CTBAD tương tự như phình động mạch chủ ngực hay phình động mạch chủ ngực-bụng. Phẫu thuật điều trị CTBAD khá phức tạp do phải xử trí vách nội mạc. Thời gian phẫu thuật kéo dài với nguy cơ chảy máu, thiếu máu tuỷ, suy thận tăng. Phình bóc tách động mạch chủ thường lan toả hơn phình do thoái hoá thành mạch và thường gặp ở bệnh nhân trẻ hơn.

Tỷ lệ yếu liệt chi trong phẫu thuật CTBAD dao động 30-35\% theo các báo cáo đầu tiên do phình bóc tách thường nhập viện trong bệnh cảnh cấp cứu, có rối loạn mô liên kết và phình động mạch chủ ngực bụng Crawford type I, II. Với sự tiến bộ của phẫu thuật, giá trị tiên đoán âm của bóc tách mãn tính đối với yếu liệt chi giảm, và không được xem là yếu tố tiên lượng của thiếu máu tuỷ trong điều trị phình động mạch chủ ngực-bụng.

Trong nhiều nghiên cứu đơn trung tâm điều trị phẫu thuật bệnh động mạch chủ phức tạp, tỷ lệ tử vong dao động từ 6-11\%, yếu liệt chi từ 3.6-12\%. Ngược lại, ở những trung tâm có số lượng bệnh nhân phẫu thuật lớn hoặc kết quả đăng bộ quốc gia cho thấy tỷ lệ tử vong của phẫu thuật điều trị bóc tách động mạch chủ cao hơn vào khoảng $20 \%$.

\begin{tabular}{|l|c|c|}
\hline Khuyến cáo 36 & $\begin{array}{c}\text { Mức độ } \\
\text { khuyến cáo }\end{array}$ & $\begin{array}{c}\text { Mức độ bằng } \\
\text { chứng }\end{array}$ \\
\hline $\begin{array}{l}\text { Phẫu thuật điều trị phình bóc tách động mạch chủ hay bóc tách } \\
\text { mãn tính có triệu chứng ở bệnh nhân nguy cơ phẫu thuật thấp } \\
\text { nên được xem xét ở những trung tâm chuyên sâu có tỷ lệ biến } \\
\text { chứng thấp }\end{array}$ & IIa & $\mathrm{C}$ \\
\hline
\end{tabular}




\begin{tabular}{|l|c|c|}
\hline Khuyến cáo 37 & \\
\hline $\begin{array}{l}\text { Ở bệnh nhân bóc tách động mạch chủ mãn tính được phẫu thuật, } \\
\text { dẫn lưu dịch não tuỷ, cầu nối tim trái, hạ thân nhiệt trung bình } \\
\text { nên được xem xét để giảm tử vong chu phẫu và chân thương tuỷ } \\
\text { sống }\end{array}$ & IIa & C \\
\hline
\end{tabular}

\subsubsection{Can thiệp nội mạch}

Can thiệp nội mạch điều trị CTBAD gia tăng từ năm 1999. Mục đích của can thiệp là che lỗ rách nguyên uỷ, tái cấu trúc động mạch chủ tạo huyết khối lòng giả, từ đó giảm khả năng vỡ động mạch chủ trong giai đoạn trung, dài hạn.

Rất ít nghiên cứu so sánh kết quả điều trị CTBAD bằng phẫu thuật và can thiệp nội mạch. Một báo cáo điều trị trên 24 bệnh nhân CTBAD cho thấy tử vong ở nhóm can thiệp nội mạch là $0 \%$ và phẫu thuật là $33 \%$. Đăng bộ quốc gia ghi nhận kết quả lâu dài khả quan hơn ở nhóm can thiệp nội mạch so với phẫu thuật điều trị bóc tách động mạch chủ. Gần đây, nhiều nghiên cứu ủng hộ can thiệp nội mạch điều trị CTBAD có tỷ lệ biến chứng thấp. Một nghiên cứu tổng quan hệ thống trên 567 bệnh nhân CTBAD được can thiệp nội mạch, tử vong chu phẫu là $3.2 \%$, đột quỵ là $0.82 \%$ và thiếu máu tuỷ sống là $0.43 \%$.

Can thiệp nội mạch điều trị CTBAD có biến chứng và tử vong thấp hơn $\mathrm{ATBAD}$ do tỷ lệ can thiệp cấp cứu cao hơn đối với ATBAD. Hiện nay, có bằng chứng mạnh khẳng định can thiệp nội mạch điều trị CTBAD có tỷ lệ tử vong $<5 \%$, biến chứng thần kinh thấp ngay cả những trường hợp có biến chứng.

Trong nghiên cứu tổng quan hệ thống nói trên, thời gian theo dõi trung bình là 26 tháng. Tỷ lệ tử vong do mọi nguyên nhân là $9.2 \%$. Tử vong liên quan đến động mạch chủ trung hạn là $4.2 \%$. Biến chứng muộn thường gặp là tiến triển phình động mạch chủ đoạn xa hoặc lòng giả tiếp tục tưới máu gây phình (7.8\%). Tỷ lệ vỡ động mạch chủ muộn là $3 \%$. Không có nghiên cứu nào ghi nhận vị trí vỡ trong lòng hay bên dưới ống ghép nội mạch.

Tỷ lệ huyết khối lòng giả hoàn toàn từ 38 $100 \%$ (trung bình $86 \%$ ) trong nghiên cứu với thời gian theo dõi trung bình 17 tháng. Theo dõi trung hạn hình thái học động mạch chủ cho thấy đường kình lòng giả giảm chiếm $79 \%$, đường kính lòng giả tăng chiếm $15 \%$, đường kính lòng thật tăng chiếm $66 \%$.

Sự tiến bộ của can thiệp nội mạch động mạch chủ ngực đã mở ra hướng điều trị cho những bệnh nhân bóc tách động mạch chủ ngực type $\mathrm{B}$ bán cấp tính. Nếu không can thiệp, một phần đáng kể bệnh nhân này sẽ tiến triển đến phình bóc tách lớn cần xử trí. Điều trị CTBAD khó khăn và đứng về phương diện can thiệp nội mạch đòi hỏi che phủ động mạch chủ ngực dài hơn do động mạch mất tính đàn hồi. Có giả thiết cho rằng một số bệnh nhân bóc tách bán cấp có những đặc tính cơ bản về sinh lý và hình thái học dẫn đến hình thành phình bóc tách mãn tính. Những bệnh nhân này nên được điều trị trong giai đoạn bán cấp tính. Can thiệp nội mạch đối với bệnh nhân bóc tách bán cấp có tỷ lệ tử vong thấp và thành động mạch chủ đàn hồi hơn so với bóc tách mãn tính. Mặc dù giả thiết này hấp dẫn, những đặc tính hình thái học tiên đoán phình bóc tách về sau chưa được định nghĩa đầy đủ, cần nghiên cứu thêm.

Nghiên cứu đối chứng ngẫu nhiên INSTEAD với bệnh nhân bóc tách động mạch chủ bán cấp và mãn tính so sánh can thiệp nội mạch sớm với điều trị nội khoa tích cực cho thấy tái cấu trúc động mạch chủ tốt hơn ở nhóm can thiệp tuy nhiên không có sự khác biệt có ý nghĩa giữa 2 
nhóm về tử vong sau 2 năm. Sau thời gian theo dõi 5 năm, can thiệp nội mạch kết hợp điều trị nội khoa tối ưu cho tỷ suất sống còn liên quan động mạch chủ và tiến triển của bóc tách tốt hơn có ý nghĩa so nhóm điều trị nội khoa đơn thuần. Tác giả kết luận rằng những trường hợp $\mathrm{CTBAD}$ ổn định có giải phẫu thích hợp, can thiệp nội mạch sớm nên được xem xét để cải thiện kết quả lâu dài.

Một vấn đề cần giải thích chi tiết hơn là can thiệp nội mạch có làm giảm tử vong liên quan đến động mạch chủ trung hạn-dài hạn. Phẫu thuật có tỷ lệ tử vong sớm liên quan động mạch chủ cao nhưng làm giảm tỷ lệ tử vong muộn liên quan động mạch chủ. Dữ liệu cho thấy can thiệp nội mạch ngăn ngừa tử vong muộn liên quan đến động mạch chủ kém hơn.

Khả năng tái cấu trúc động mạch chủ sau can thiệp nội mạch bóc tách cấp và mãn tính đã được nghiên cứu. Sau khi che phủ được lỗ rách nguyên uỷ của $\mathrm{ATBAD}$, đường kính lòng thật tăng và lòng giả giảm. Ngược lại, đối với CTBAD, tái cấu trúc động mạch chủ kém hơn, chủ yếu là lòng giả tạo huyết khối sau can thiệp. Trong điều trị CTBAD, huyết khối lòng giả xảy ra thường xuyên hơn đối với những trường hợp bóc tách ít và thường ở phần động mạch chủ xuống được đặt ống ghép nội mạch. Điều này cho thấy mức độ che phủ động mạch chủ xuống liên quan đến mức độ huyết khối lòng giả. Mặc dù thiếu máu tuỷ sống sau can thiệp đối với CTBAD thấp hơn so với phình động mạch chủ ngực, nhưng nếu che phủ động mạch chủ ngực xuống càng dài sẽ làm tăng nguy cơ thiếu máu tuỷ. Để giảm tỷ lệ này, tưới máu tuỷ sống cần được duy trì thông qua tuần hoàn bàng hệ, đặc biệt là từ động mạch dưới đòn trái. Dù che phủ động mạch dài đến đâu thì đoạn động mạch chủ bóc tách dưới cơ hoành vẫn không được điều trị và sẽ tiến triển theo thời gian. Vai trò của giá đỡ nội mạch trần trong điều trị bóc tách mãn tính và hiệu quả trong tái cấu trúc thành động mạch chủ vẫn chưa được xác định tính tới thời điểm hiện tại.

Y văn đề cập can thiệp nội mạch đối với CTBAD ở bệnh nhân Marfan vẫn còn thưa thớt. Về mặt kỹ thuật thì khả thi nhưng kết quả lâu dài thì không chắc chắn. Thành động mạch chủ mỏng manh ở bệnh nhân Marfan và một số tình trạng phối hợp khác gây khó khăn cho cố định động mạch chủ đầu gần và có thể gây nên biến chứng. Gần đây, một số kỹ thuật mới đã được kiểm tra để tạo ra huyết khối lòng giả trong điều trị CTBAD. Mặc dù tính khả thi và hữu ích đã được chứng minh trên một số bệnh nhân ở những trung tâm chuyên sâu, còn quá sớm để chấp nhận rộng rãi và đưa ra khuyến cáo về vấn đề này.

\begin{tabular}{|l|c|c|}
\hline \multicolumn{1}{|c|}{ Khuyến cáo 38} & $\begin{array}{c}\text { Mức độ } \\
\text { khuyến cáo }\end{array}$ & $\begin{array}{c}\text { Mức độ bằng } \\
\text { chứng }\end{array}$ \\
\hline $\begin{array}{l}\text { Ở những bệnh nhân nguy cơ phẫu thuật cao hay trung bình hay } \\
\text { chống chỉ định phẫu thuật, can thiệp nội mạch điều trị bóc tách } \\
\text { động mạch chủ mãn tính nên được xem xét ở những trung tâm } \\
\text { chuyên sâu }\end{array}$ & IIa & C \\
\hline Khuyến cáo 39 & & \\
\hline $\begin{array}{l}\text { Ở những bệnh nhân nguy cơ có biến chứng liên quan động mạch } \\
\text { chủ với giải phẫu học thích hợp, can thiệp nội mạch đối với bóc } \\
\text { tách type B mãn tính không có biến chứng nên được xem xét can } \\
\text { thiệp ở giai đoạn bán cấp tại những trung tâm chuyên sâu. }\end{array}$ & IIa & B \\
\hline
\end{tabular}




\section{TÀI LIỆU THAM KHẢO}

1. Estrera AL, Miller CC, Goodrick J, Porat EE, Achouh PE, Dhareshwar J, et al. Update on outcomes of acute type B aortic dissection. Ann Thorac Surg 2007;83:S842e5.

2. Trimarchi S, Eagle KA, Nienaber CA, Pyeritz RE, Jonker FH, Suzuki T, et al. Importance of refractory pain and hyperten- sion in acute type B aortic dissection: insights from the International Registry of Acute Aortic Dissection (IRAD). Circulation 2010;122:1283e9.

3. Trimarchi S, Tolenaar JL, Tsai TT, Froehlich J, Pegorer M, Upchurch GR, et al. Influence of clinical presentation on the outcome of acute B aortic dissection: evidences from IRAD. J Cardiovasc Surg (Torino) 2012;53:161e8.

4. Suzuki T, Isselbacher EM, Nienaber CA, Pyeritz RE, Eagle KA, Tsai TT, et al. Typeselective benefits of medications in treat- ment of acute aortic dissection (from the International Reg- istry of Acute Aortic Dissection [IRAD]). Am J Cardiol 2012;109:122e7.

5. Hagan PG, Nienaber CA, Isselbacher EM, Bruckman D, Karavite DJ, Russman PL, et al. The International Registry of Acute Aortic Dissection (IRAD): new insights into an old disease. J Am Med Assoc 2000;283:897e903.

6. Tsai TT, Trimarchi S, Nienaber CA. Acute aortic dissection: perspectives from the International Registry of Acute Aortic Dissection (IRAD). Eur J Vasc Endovasc Surg 2009;37:149e59.

7. Suzuki T, Mehta RH, Ince H, Nagai R, Sakomura Y, Weber F, et al. Clinical profiles and outcomes of acute type B aortic dissection in the current era: lessons from the International Registry of Aortic Dissection (IRAD). Circulation 2003;108(Suppl. 1):II312e7.

8. Elefteriades JA. Natural history of thoracic aortic aneurysms: indications for surgery, and surgical versus nonsurgical risks. Ann Thorac Surg 2002;74:S1877e80.

9. Neal B, MacMahon S, Chapman N. Effects of ACE inhibitors, calcium antagonists, and other blood-pressure-lowering drugs: results of prospectively designed overviews of rando- mised trials. Blood Pressure Lowering Treatment Trialists' Collaboration. Lancet 2000;356:1955e64.
10. Eggebrecht H, Schmermund A, von Birgelen C, Naber CK, Bartel T, Wenzel RR. Resistant hypertension in patients with chronic aortic dissection. J Hum Hypertens 2005;19: 227e31.

11. Eggebrecht $H$, Nienaber $\mathbf{C A}$, Neuhauser $M$, Baumgart D, Kische S, Schmermund A, et al. Endovascular stent graft placement in aortic dissection: a meta-analysis. Eur Heart J 2006;27:489e98.

12. Cambria RP, Clouse WD, Davison JK, Dunn PF, Corey M, Dorer D, et al. A multicenter clinical trial of endovascular stent graft repair of acute catastrophes of the descending thoracic aorta. J Vasc Surg 2009;50:1255e64.

13. Zeeshan A, Woo EY, Bavaria JE, Fairman RM, Desai ND, Pochettino A, et al. Thoracic endovascular aortic repair for acute complicated type B aortic dissection: superiority rela- tive to conventional OS and medical therapy. J Thorac Car- diovasc Surg 2010;140(Suppl.):S109e15.

14. Svensson LG, Kouchoukos NT, Miller DC, Bavaria JE, Coselli JS, Curi MA, et al. Expert consensus document on the treatment of descending thoracic aortic disease using endovascular stent grafts. Ann Thorac Surg 2008;85:S1e41.

15. Umana JP, Lai DT, Mitchell RS, Moore KA, Rodriguez F, Robbins RC, et al. What is the best treatment for patients with acute type B aortic dissections e medical, surgical, or endovascular stent grafting? Ann Thorac Surg 2002;74: S1840e3.

16. Verhoye JP, Miller DC, Sze D, Dake MD, Mitchell RS. Compli- cated acute type B aortic dissection: midterm results of emergency endovascular stent grafting. J Thorac Cardiovasc Surg 2008; 136:424e30.

17. Steuer J, Eriksson MO, Nyman R, Bjorck M, Wanhainen A. Early and long-term outcome after thoracic endovascular aortic repair (TEVAR) for acute complicated type B aortic dissection. Eur J Vasc Endovasc Surg 2011;41:318e23.

18. Fattori R, Tsai TT, Myrmel T, Evangelista A, Cooper JV, Trimarchi S, et al. Complicated acute type B dissection: is surgery still the best option?: a report from the International Registry of Acute Aortic Dissection. JACC Cardiovasc Interv 2008;1:395e402. 